\title{
Uji Antagonis Jamur Gliocladium sp dalam Menghambat Pertumbuhan Jamur Fusarium sp Penyebab Penyakit Layu Pada Tanaman Pisang (Musa paradisiaca $\mathbf{L}$.)
}

\section{The Antagonist Test of Gliocladium sp Fungus on the growth inhibiting of the Fusarium sp that Cause Wilt Diseases in Banana (Musa paradisiaca L.)}

\author{
Taufiq Hidayat ${ }^{1}{ }^{*}$, Ahmad Syauqi $\left.^{2 * *}\right)$, Tintrim Rahayu ${ }^{3}$ \\ ${ }^{123}$ Jurusan Biologi Fakultas Matematika dan Ilmu Pengetahuan Alam Universitas Islam Malang, Indonesia
}

\begin{abstract}
ABSTRAK
Jamur Gliocladium sp. merupakan mikroba tanah yang dapat diisolasi dari daerah perakaran tanaman pisang (Musa Paradica L.) Jamur tersebut termasuk dalam kelompok mikroba antagonis yang berpotensi dalam menghambat pertumbuhan jamur Fusarium sp yang menginfeksi tanaman yang menyebabkan penyakit layu pada tanaman pisang. Penelitian ini bertujuan untuk mengetahui perbedaan persentase daya hambat jamur Gliocladium sp. dalam menghambat pertumbuhan jamur Fusarium sp. pada pH 5,5 dan pH 7. Penelitian ini menggunakan metode deskriptif dan eksperimen. Hasil dari persentase daya hambat hari terakhir lebih tinggi pada $\mathrm{pH} 5,5$ sebesar 35,2\% sedangkan pada $\mathrm{pH} 7$ sebesar $14 \%$. Hal ini menandakan bahwa pertumbuhan jamur lebih cocok di $\mathrm{pH}$ mendekati asam karena sifatnya yang mampu menyesuaikan dengan metabolisme jamur. Mekanisme Penghambatan jamur Gliocladium sp. kepada jamur Fusarium sp. mempunyai tahap kompetisi, lisis dan mikoparasit.
\end{abstract}

Kata kunci: Gliocladium sp., Fusarium sp., tanaman pisang, $\mathrm{pH}$

\begin{abstract}
The fungus Gliocladium $\underline{\mathrm{sp}}$. is the microbial soil that can be isolated from the root zone of banana plant (Musa Paradica L.) Those fungi are included in the group of potentially antagonistic microbes in the growth inhibiting of Fusarium $\mathrm{sp}$ fungus which infects the plants and it cause disease on banana crops withered. This research aim was to know the difference of growth inhibiting percentage of Gliocladium $\underline{\mathrm{sp}}$, to the Fusarium sp. fungus at $\mathrm{pH} 5.5$ and $\mathrm{pH}$ 7. This research uses experiment methods. The results of the growth inhibiting percentage in the last day was higher at pH 5.5 of $35.2 \%$ whereas at $\mathrm{pH} 7$ of $14 \%$. This indicates that the growth of the fungus is more suitable in $\mathrm{pH}$ acidic approach because of its nature which is able to adjust to the fungal metabolism. The inhibition mechanism of the Gliocladium $\underline{\mathrm{sp}}$. on fungus inhibiting of Fusarium $\underline{\mathrm{sp}}$. has the stages of the competition, lysis and mycoparasit.
\end{abstract}

Keywords: $\underline{\text { Gliocladium }} \underline{\mathrm{sp}}$, $\underline{\text { Fusarium }} \underline{\mathrm{s}}$, banana plants, $p H$

\footnotetext{
*) Taufiq Hidayat, Jurusan Biologi FMIPA UNISMA, J1. MT Haryono 193, Malang 65144. Telp. 082335981701 and Email: taufiqhidayatm502@gmail.com

${ }^{* * *}$ Ir. Ahmad Syauqi, M.Si., Jurusan Bologi FMIPA UNISMA, Jl. MT Haryono 193, Malang 65144 Telp. 08986307836 Email: Syauqi.fmipa@unisma.ac.id
} 


\section{Pendahuluan}

Mahluk hidup seperti manusia, hewan dan tumbuhan dalam kehidupannya tidak pernah lepas dari peranan mahluk hidup mikroorganisme. Semakin berkembangnya zaman, ilmu mikrobiologi semakin mengalami kemajuan yang sangat pesat dengan ditambah oleh bantuan penemuan alat seperti mikroskop elektron dan perkembangan komputerisasi.

Pisang (Musa paradisiaca L.) merupakan komuditas unggulan di Indonesia, Balai Penelitian Tanaman Buah Tropika 2009 melaporkan bahwa komoditas ini menjadi kontributor utama terhadap produksi buah unggulan secara nasional dengan persentase mencapai $31 \%$ dibandingkan dengan jeruk (16\%), mangga (10\%), durian (5\%), dan buah-buahan lainnya (38\%).

Akan tetapi keberhasilan kegiatan pengembangan komoditas pisang di Indonesia tidak serta merta lepas dari serangan penyakit organisme pengganggu tanaman (OPT), tercatat serangan OPT paling berbahaya yang menyerang pertumbuhan pisang dan bahkan dianggap sebagai ancaman bagi industri pisang dunia yaitu adalah serangan penyakit Antagonis Fusarium sp. Di Indonesia, penyakit Fusarium sp yang menyebabkan layu terhadap tanaman pisang ini dilaporkan telah menghancurkan ribuan hektar pertanaman pisang baik perkebunan pisang komersial maupun pertanaman pisang rakyat yang telah menyebar mulai dari NAD sampai ke Papua [1].

Fusarium sp merupakan suatu patogen yang dapat menyebabkan penyakit terhadap suatu tanaman salah satunya adalah pisang. Gejala awal penyakit ditandai dengan adanya perubahan warna pada bagian pucuk tanaman kemudian bagian tersebut akan menjadi layu. Gliocladium sp merupakan suatu agen hayati mikroorganisme yang dapat menghasilkan antibiotik yang terjadi secara alami dan telah banyak digunakan sebagai agen pengendali organisme pengganggu tanaman (OPT)[2].

\section{Material dan Metode}

\section{Bahan dan Alat}

Bahan yang digunakan dalam penelitian skripsi ini adalah : Jamur Gliocladium sp yang diisolasi dari rizozfer tanah, jamur patogen Fusarium sp yang diisolasi dari layu tanaman pisang, Media Potato Dexstrose Agar (PDA), alkohol 70\%, amoksilin 1\%, asam posfat $\left(\mathrm{H}_{3} \mathrm{PO}^{4}\right)$, Buffer Posfat Saline (BPS), spiritus, aquades.

Alat yang digunakan dalam penelitian skripsi ini adalah : Mikroskop, cawan petri, erlenmeyer $250 \mathrm{ml}$, gelas beaker $500 \mathrm{ml}$, gelas ukur, gelas arloji, $\mathrm{pH}$ meter, tabung reaksi, inkubator, timbangan analitik untuk menimbang sampel dan media, hot plate, magnetic stirrer, jarum oase, pipet tetes, Laminar Air Flow (LAF), oven, kapas, tissue bunsen, pinset, spatula, korek api, alat tulis, kompor, autoklaf, wrepping, gunting, cutter, kertas label, hp untuk dokumentasi, kompor gas, tabung elpigi, kertas sampul dan karet gelang untuk sterilisasi alat dan laptop.

\section{Metode}

Metode yang digunakan dalam penelitian adalah metode deskriptif yang meliputi penelitian pendahuluan, dan metode eksperimen yang meliputi isolasi dan pemurnian sampel jamur Gliocladium sp dan jamur patogen Fusarium sp. Konteks tempat pengambilan sampel adalah tempat yang sesuai yang diinginkan oleh peneliti. Uji antagonis jamur Gliocladium sp dalam menghambat pertumbuhan jamur patogen Fusarium sp terdapat dua perlakuan yaitu pada $\mathrm{pH} 7$ dan $\mathrm{pH} 5,5$ dengan 5 kali ulangan.

\section{Cara Kerja}

Sterilisasi Alat: Alat-alat yang akan digunakan dalam penelitian ini dicuci kemudian dikeringkan. Alat-alat seperti cawan petri, gelas ukur, dibungkus dengan kertas sampul dan diikat menggunakan karet gelang. Sedangkan alat-alat seperti erlenmeyer dan tabung reaksi ditutup terlebih dahulu bagian mulut alat dengan kapas kemudian ditutup dengan kertas sampul dan diikat dengan karet gelang. 
Kemudian disterilisasi dengan menggunakan autoklaf pada suhu $121^{\circ} \mathrm{C}$ pada tekanan 15 pounds. Saat suhu dan tekanan telah tercapai, dibiarkan selama 15 menit. Kemudian dibuka autoklaf dan diambil semua alat yang sudah di sterilisasi kemudian dikeringkan menggunakan oven sampai suhu mencapai $80^{0} \mathrm{C}[3]$

Pembuatan Media Potato Dexstrose Agar (PDA): Pembuatan media Potato Dexstrose Agar (PDA) yaitu dengan menimbang PDA 22,5 gram dan dilarutkan dengan 1 liter aquades steril. Media dicairkan kedalam erlenmeyer, kemudian didihkan menggunakan hot plate sambil diaduk menggunakan magnetic stirrer. Setelah media mendidih dan homogen kemudian media dituang kedalam tabung reaksi dan ditutup bagian mulut dengan kapas lalu dibungkus dengan kertas sampul dan diikat dengan karet gelang. Disterilisasi menggunakan autoklaf pada suhu $121^{\circ} \mathrm{C}$ pada tekanan 15 pounds. Dibiarkan selama 15 menit kemudian dibuka autoklaf lalu kemudian media PDA di ambil dan dituang kedalam cawan petri serta tabung reaksi steril $\pm 15 \mathrm{~mL}$ secara aseptis

Isolasi Jamur Fusarium sp.: Isolasi jamur Patogen Fusarium sp dimulai dari sumber inokulum yang diambil dari tanaman pisang yang terserang penyakit layu Fusarium sp Gejala luar yang khas yaitu daun menguning, terjadinya layu sepihak atau keseluruhan, batang bawah berubah warna menjadi kecoklatan dan bila batang dibelah secara membujur maupun melintang terlihat jaringan xylem berwarna coklat, kemerahan, kehitaman ataupun kekuningan. Bagian tanaman (batang, daun dan akar) yang terserang penyakit Fusarium sp dibersihkan dengan air steril, lalu dipotong tipis dengan panjang $1 \mathrm{~cm}$. Setelah itu disterilkan dengan amoksilin $1 \%$ selama kurang lebih 1 menit dan dibilas 2 kali dengan aquades steril, selanjutnya potongan tersebut ditanam dalam media Potato Dextrose Agar (PDA) dengan cara aseptis yang dilakukan di dalam LAF (Laminar Air Flow) kemudian diinkubasi pada suhu ruang selama 1 minggu. Mikroorganisme yang tumbuh diidentifikasi jenisnya berdasarkan kriteria pengamatan makroskopis yaitu profil dan warna koloni, pada media media Potato Dextrose Agar (PDA), dan pengamatan secara mikroskopis berdasarkan [4].

Isolasi Jamur Gliocladium sp.: Isolasi jamur Gliocladium sp diambil dari rizozfer tanah disekitar perakaran tanaman pisang yang sehat. Tanah diambil dengan kedalam $25 \mathrm{~cm}$, kemudian ditimbang sebanyak 15 gr dan ditaburkan pada media Potato Dextrose Agar (PDA) dengan cara aseptis yang dilakukan didalam LAF (Laminar Air Flow). Diinkubasi pada suhu ruang selama 1 minggu, mikroorganisme yang tumbuh diidentifikasi jenisnya berdasarkan kriteria pengamatan makroskopis yaitu profil dan warna koloni pada media Potato Dextrose Agar (PDA), dan pengamatan secara mikroskopis berdasarkan [5].

Pemurnian isolate: Setelah jamur teridentifikasi berdasarkan kriteria makroskopis dan mikroskopis kemudian jamur Gliocladium sp dan jamur patogen Fusarium sp dimurnikan kembali secara aseptis didalam LAF (Laminar Air Flow) dengan menumbuhkan isolat pada media Potato Dextrose Agar (PDA). Pertama disiapkan jarum oase, bunsen, korek api, alkohol $70 \%$ dalam gelas beaker. Dinyalakan bunsen dan dilakukan seleksi koloni pada biakan jamur patogen Fusarium sp dan jamur endofit Gliocladium sp kemudian diambil menggunakan jarum oase digesekkan pada koloni yang terpilih dan inokulasikan kedalam media Potato Dextrose Agar (PDA), setiap akan mengisolasi koloni dilakukan pembakaran jarum oase hingga membara pada bunsen. Ketika jarum tidak digunakan maka maka jarum dicelupkan kedalam gelas beaker yang berisi alkohol $70 \%$. Kemudian cawan petri dibungkus menggunakan kertas sampul dan tabung reaksi ditutup menggunakan kapas, dibungkus dengan kertas sampul dan diikat dengan karet gelang, cawan petri dan tabung reaksi di inkubasi selama 1 minggu dengan menggunakan suhu ruang.

Pembuatan Media Potato Dextrose Agar (PDA) pH 7: Diambil Buffer Posfat Saline (BPS) dan aquades sebanyak $50 \mathrm{~mL}$, dan dimasukkan kedalam gelas beaker $250 \mathrm{~mL}$ kemudian ditambahkan bubuk instan Potato Dextrose Agar (PDA) sebanyak 4 gram. Ditetesi $\mathrm{NaOH}$ yang sudah di encerkan dengan aquades hingga $\mathrm{pH} 7$, setelah $\mathrm{pH}$ sesuai media dicairkan kedalam erlenmeyer, kemudian di didihkan menggunakan hot plate sambil diaduk menggunakan magnetic stirrer. 
Pembuatan Media Potato Dextrose Agar (PDA) pH 5,5: Diambil Buffer Posfat Saline (BPS) aquades sebanyak $37 \mathrm{~mL}$ dan dimasukkan kedalam gelas beaker $100 \mathrm{~mL}$ kemudian ditambahkan bubuk instan Potato Dextrose Agar (PDA) sebanyak 3 gram. Kemudian ditetesi Asam posfat $\left(\mathrm{H}_{3} \mathrm{PO}^{4}\right)$ yang sudah di encerkan dengan Aquades hingga $\mathrm{pH}$ menjadi 5,5. setelah $\mathrm{pH}$ sesuai media dicairkan kedalam erlenmeyer, kemudian di didihkan menggunakan hot plate sambil diaduk menggunakan magnetic stirrer.

Uji Antagonis: Uji Antagonis dilakukan dengan metode biakan ganda (dual culture) yang dilakukan secara in vitro. Koloni jamur Gliocladium sp dan jamur patogen Fusarium sp diinokulasi menggunakan jarum ose steril berdiameter $0,5 \mathrm{~cm}$ diletakkan $3 \mathrm{~cm}$ pada media Potato Dextrose Agar (PDA) $\mathrm{pH} 7$ dan $\mathrm{pH}$ 5,5 dibagian masing-masing tepi cawan petri yang berdiameter $9 \mathrm{~cm}$ dengan jarak $3 \mathrm{~cm}$, kemudian diinkubasi pada suhu ruang. Pengamatan terhadap luas miselium jamur Gliocladium sp dan jamur patogen Fusarium sp dimulai dari hari ke-1 sampai hari ke-6 (uji kontrol penuh).

Selanjutnya melakukan pengamatan dengan mengukur diameter jamur e Gliocladium sp dan patogen Fusarium sp dengan menggunakan penggaris ukur kemudian mencatat hasil pengamatan yang didapat. Pengamatan dilakukan setelah inokulasi pada kedua perlakuan yaitu pada $\mathrm{pH} 7 \mathrm{dan} \mathrm{pH}$ 5,5, pertumbuhan jamur Gliocladium sp dan jamur patogen Fusarium sp diukur lebar secara horizontal dan vertikal dengan menggunakan penggaris. Persentase daya hambat dihitung dengan menggunakan rumus sebagai berikut [6] :

$$
P=\frac{r 1-r 2}{r 1} \times 100 \%
$$

\footnotetext{
Keterangan:

$\mathrm{P}=$ Persentase (\%) daya hambat jamur Gliocladium sp terhadap jamur Fusarium sp

r1 = Panjang diameter Fusarium sp pada perlakuan kontrol

r2= Panjang diameter Fusarium sp pada perlakuan uji antagonis
}

Analisis Data: Pengamatan dilakukan terhadap kemampuan jamur Gliocladium sp dalam menghambat pertumbuhan jamur patogen Fusarium sp penyebab penyakit layu pada tanaman pisang dengan perlakuan $\mathrm{pH}$ yang berbeda, yaitu $\mathrm{pH} 5,5$ dan $\mathrm{pH}$ 7. Data dianalisis secara deskriptif dengan disajikan dalam bentuk tabel dan grafik, serta gambar dokumentasi. Analisis uji T pH 5,5 dan pH 7 untuk mengetahui berpengaruh atau tidak nya dari kedua perlakuan populasi data.

\section{Hasil dan Diskusi}

Karakteristik makroskopis jamur diamati secara langsung dengan melihat perkembangan masing-masing koloni yang dibedakan berdasarkan warna koloni dan profil koloni yang ditumbuhkan pada media Potato Dextrose Agar (PDA). Sedangkan pengamatan secara mikroskopis hanya berdasarkan bentuk Konidium yang diamati dibawah pengamatan mikroskop. Pengamatan karakteristik pada masing-masing jamur dilakukan pada hari ke-6 setelah isolasi biakan murni.

Setelah dilakukan pengamatan karakteristik makroskopis yang diduga jamur Fusarium sp maka untuk mendapatkan temuan yang lebih valid dilakukan pengamatan secara mikroskopis. Jamur Fusarium sp umunya mempunyai 3 alat reproduksi yaitu Makrokonidium, Mikrokonidium, dan Klamidospora. Makrokonidium merupakan organ aseksual dalam siklus hidup Fusarium sp, selain sebagai alat infeksi sebagai patogen tumbuhan, makrokonidium penting dalam penyebaran propagul Fusarium sp, dan pada hasil penelitian ini menunjukkan makrokonidium yang cukup melimpah dengan bentuk menyerupai bulan sabit. Mikrokonidium sama halnya dengan makrokodium, 
mikrokonidium merupakan alat reproduksi aseksual dalam sistem reproduksi sekunder pada daur hidup Fusarium sp dengan karakteristik berbentuk bulat halus seperti telur dibagian tengah makrokonidium [7]. Sedangkan Klamidospora adalah pembentukan spora dari suatu hifa pada bagian tengahnya membentuk tonjolan protoplasma, dan selanjutnya protoplasma terbagi-bagi menjadi spora.

Tabel 1. Karakteristik Makroskopis dan Mikroskopis Jamur Fusarium sp dan Gliocladium sp.

\begin{tabular}{|c|c|c|c|c|}
\hline \multirow{2}{*}{ No } & \multirow{2}{*}{ Jenis Jamur } & \multicolumn{2}{|c|}{ Karakteristik Makroskopis } & $\begin{array}{c}\text { Karakteristik } \\
\text { Mikroskopis }\end{array}$ \\
\cline { 3 - 5 } & & Warna Koloni & Profil Koloni & Konidium \\
\hline 1 & Fusarium sp. & Putih tepi merah muda & halus & Berbentuk bulan sabit \\
\hline 2 & Gliocladium sp. & Hijau kehitaman & kasar & Berbentuk bulat \\
\hline
\end{tabular}
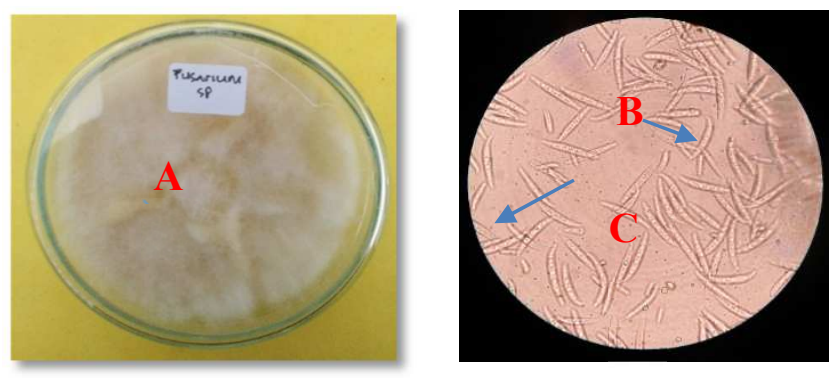

Gambar 1. Koloni jamur Fusarium sp. (A) Makronkonidium (B) Mikrokonidium (C)
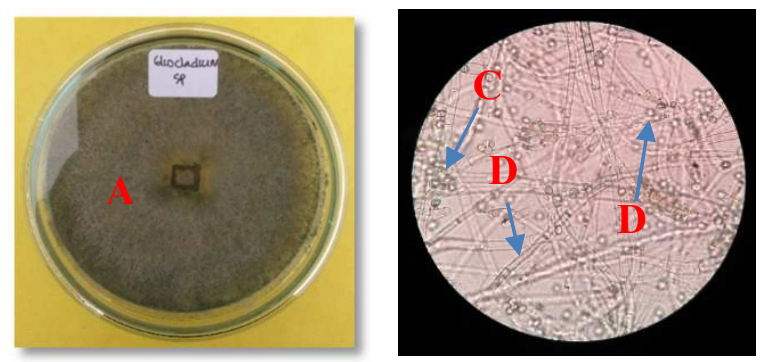

Gambar 2. Koloni jamur Gliocladium sp (A) Hifa (B) Konidia (C) Konidiofora(D)

Setelah dilakukan pengamatan secara makroskopis yang diduga jamur Gliocladium sp maka untuk mendapatkan data yang lebih valid dilakukan pengamatan secara mikroskopis. Genus cendawan ini memiliki konidiofor lurus dan bercabang-cabang pada ujungnya. Percabangan hifanya kompak dan membentuk struktur penicilliate. Konidianya berbentuk bulat, hialin dan membentuk suatu kumpulan bintik-bintik spora berwarna hijau. . Karakteristik ini sesuai apa yang dikemukakan oleh Anderson [8] bahwa karakteristik Gliocladium sp secara mikroskopis konidiofornya 
berbentuk kuas padat (penicillate), konidia bersel satu, hialin atau terpigmen cerah berdinding halus. Disamping konidiofornya berbentuk kuas namun ada juga yang konidiofornya terpusat sederhana (verticillate).

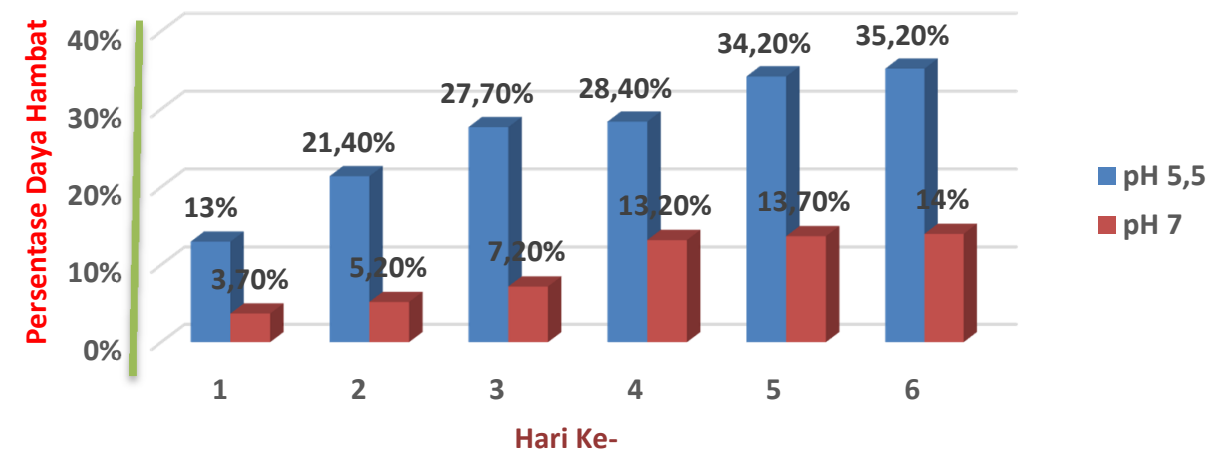

Gambar 3. Persentase (\%) Daya Hambat Jamur Gliocladium sp Terhadap Pertumbuhan Jamur Fusarium sp pH 5,5 dan pH 7.

Kemampuan penghambatan uji antagonis jamur Gliocladium sp dalam menghambat pertumbuhan jamur patogen Fusarium sp dapat diketahui dalam bentuk perbandingan angka, dimana pada hasil penelitian ini lebih signifikan pada $\mathrm{pH}$ 5,5 dibandingkan pada $\mathrm{pH}$ 7. Daya hambat yang dihasilkan pada $\mathrm{pH}$ 5,5 setiap harinya terus mengalami penghambatan pertumbuhan yang cukup baik, tercatat dari hari pertama hanya sebesar 13\% hingga hari terkahir meningkat mencapai angka sebesar $35,2 \%$. Sedangkan pada $\mathrm{pH} 7$ jamur Gliocladium sp mengalami penuruan daya hambat, tercatat dari hari pertama sebesar 3,7\% hingga hari terkahir meningkat hanya mencapai angka sebesar $14 \%$. hal ini dikarenakan antibiotik yang dihasilkan jamur endofit Gliocladium sp kurang maksimal. Hasil penelitian ini sesuai dengan apa yang dikatakan [9] bahwa pertumbuhan jamur lebih cocok hidup di $\mathrm{pH}$ asam karena sifatnya yang mampu menyesuaikan dengan metabolisme jamur yang sedikit lemah, jamur pada $\mathrm{pH}$ 5,5 dapat tumbuh dengan baik karena jamur mampu melakukan stabilitas $\mathrm{pH}$ isi selnya secara efisien, oleh karena itu jamur membutuhkan $\mathrm{pH}$ yang sesuai aktivitas enzim secara optimal. Sehingga tidak heran apabila pada $\mathrm{pH}$ basa pertumbuhan akan didominasi oleh bakteri sedangkan pada $\mathrm{pH}$ netral $(7,0)$ jamur mampu bertahan hidup karena sifatnya yang kurang asam dan basa.

Jamur Gliocladium sp pada biakan dual culture secara makroskopis dalam melakukan mekanisme pengambatan terhadap jamur patogen Fusarium sp terjadi secara kompetisi dan lisis. Mekanisme kompetisi terjadi pada awal pertumbuhan, yang mengakibatkan miselium jamur patogen Fusarium sp terdesak, sehingga tidak mendapatkan ruang untuk tumbuh dan akhirnya jamur patogen Fusarium sp tidak berkembang secara signifikan. Kemampuan kompetisi antara jamur patogen Fusarium sp dengan jamur Gliocladium sp menyebabkan jamur patogen Fusarium sp tidak mempunyai ruang untuk hidup, sehingga pertumbuhannya terhambat. Mekanisme lisis ditandai dengan berubahnya warna hifa cendawan patogen Fusarium sp menjadi kuning dan kemudian hancur. Konidia jamur Gliocladium sp dapat menyerang hifa jamur patogen Fusarium sp bahkan ada yang mampu menembus jamur patogen kemudian memanfaatkan isi selnya untuk nutrisi jamur Gliocladium sp [10].

Dari hasil mikoparasit yang diamati secara mikroskopis, hifa dari jamur Gliocladium sp mampu melakukan penetrasi kedalam dinding sel jamur patogen Fusarium sP. Proses mikoparasit diawali dari konidia Gliocladium sp menempel pada hifa patogen Fusarium sp kemudian terjadi penetrasi 
sehingga hifa Fusarium sp mengalami kerusakan. Mikoparasit yang dilakukan oleh Gliocladium sp menyebabkan hifa Fusarium sp kehilangan tugor dan isi selnya keluar [11]. Selain itu, Gliocladium sp yang diisolasi sebagai agen dari biokontrol alami dari tanah mampu menjadi mikoparasit terhadap jamur patogen Fusarium sp dengan cara membelit dan melubangi hifa cendawan inangnya.

\section{Kesimpulan}

Berdasarkan hasil penelitian dapat disimpulkan bahwa Daya hambat uji antagonis jamur endofit Gliocladium sp dalam menghambat pertumbuhan jamur patogen Fusarium sp lebih besar di $\mathrm{pH}$ asam $(5,5)$ dengan persentase hari terakhir sebesar 35,2\% sedangnkan pada $\mathrm{pH}$ netral (7) hanya sebesar 14\%. Sedangkan Mekanisme penghambatan jamur endofit Gliocladium sp dalam menghambat jamur patogen Fusarium sp melalui tahap makroskopik dan tahap mikroskopik. Tahap makroskopis terjadi secara kompetisi, dan lisis. Sedangkan pada tahap mikroskopik terjadi secara mikoparasit.

\section{Daftar Pustaka}

[1] Hermanto, 2011. Incidence and distribution of Fusarium wilt disease in Indonesia. International ISHS-Promusa Symposium on Global Perspective on Asian Challeges. ISHS Acta Horticulture, 828. pp.

[2] Chehri, K, Saeed, TJ, Kasa, RNR, Saeed, A and Baharuddin S 2010. Occurrence of Fusarium spp. and Fumonisins in stored wheat grains marketed in Iran. Toxins, vol. 2, pp. 2816-23.

[3] Amalia T.K., Mukhtar I.P., Syahrial Oemry, 2014. Penggunaan Jamur Endofit untuk Mengendalikan Fusarium oxysporum f.sp. capsici dan Alternaria solani Secara in Vitro. Program Studi Agroekoteknologi. Fakultas Pertanian, USU, Medan

[4] Syauqi, A. 2015. Petunjuk Praktikum Mikro Biologi Umum. Laboratorium Pusat Unisma, Malang.

[5] Juniawan, 2015. Mengenal Jamur Fusarium Oxysporum. Balai Besar Pelatihan Pertanian Ketindan, Malang.

[6] Barnett, H.L.and Hunter, B.B.1998. Illustrated Genera of Imperfecti fungi. Burgess Publishing Company. Minneapolis.

[7] Lelana, EN., Anggraeni,I., Mindawati, N. 2015. Uji Antagonis Aspergillus sp. Dan Trichoderma spp. Terhadap Fusarium sp., Penyebab Penyakit Rebah Kecambah Pada Sengon. Jurnal Penelitian Hutan Tanaman Vol. 12 No. 1, April 2015: 23-28

[8] Ohara, 2004. REN1 is Required for Development of Microconidia and Macroconidia, but Not of Chlamydospores, in the Plant Pathogenic Fungus, Genetics 166: 113-124. DOI:10.1534/genetics.166.1.113

[9] Asmirandah, Nuryanti, D., Wardana, E., Fitri, Abdullah, F., Bura L, F. 2016. Pengaruh pH Terhadap Pertumbuhan Bakteri. Jurusan Farmasi, Politehnik Kesehatan. Makasaar

[10] Talanca, A.H. 2005. Uji berbagai media biakan massal Trichoderma spp. dan aktifitas Trichoderma sp. Terformulasi terhadap cendawan patogen tular tanah. J. Stigma XII(4):600-605.

[11] Gupta VP., Tewari, SK., Govindaiah, Bajpai, AK. 1999. Ultrastructure of Mycoparasitism of Trichoderma, Gliocladium and Laetisaria species on Botryodiplodia theobromae. Phytopathol (147):1924. 